\title{
Translational medical research and liver transplantation: systematic review
}

\author{
Lucas Souto Nacif, Vera Kim, Flavio Galvão, Suzane Kioko Ono, Rafael Soares Pinheiro, Flair José \\ Carrilho, Luiz Carneiro D'Albuquerque
}

Disciplina de Transplante de Figado e Orgaos do Aparelho Digestivo, Departamento de Gastroenterologia, Hospital das Clinicas HCFMUSP, Faculdade de Medicina, Universidade de Sao Paulo, São Paulo, Brazil

Contributions: (I) Conception and design: All authors; (II) Administrative support: None; (III) Provision of study materials or patients: None; (IV) Collection and assembly of data: LS Nacif, V Kim, F Galvão, RS Pinheiro, SK Ono; (V) Data analysis and interpretation: All authors; (VI) Manuscript writing: All authors; (VII) Final approval of manuscript: All authors.

Correspondence to: Lucas Souto Nacif, MD, MSc, PhD. Rua Dr. Enéas de Carvalho Aguiar, 255-9o andar, sala 9113/9114 CEP 05403-900, São Paulo, Brazil. Email: lucasnacif@usp.br.

\begin{abstract}
Translational medicine has become a priority, but there is still a big difference between the arrival of new treatments and investment. Basic science should not be neglected because the translation from basic research is not sustained in the absence of basic research. The purpose of this literature review was to analyze the translational medicine in the liver transplant field: liver ischemia-reperfusion injury (IRI), immunosuppression, clinical and surgical complications, small-for-size syndrome (SFSS), rejection, and ongoing innovations (liver machine, liver preservation, artificial livers, and regenerative medicine). We performed a systematic literature review that were updated in October 2016. The searches were performed in the Cochrane Central Register of Controlled Trials and Review, PubMed/Medline, Embase, and LILACS databases. All the selected studies on the management of translational medical research in liver transplantation (LT) were analyzed. Initially the search found 773 articles. Methodological viewing and analysis of the articles, followed by the application of scientific models, including translational medicine in the liver transplant field. In conclusions, this review demonstrates the application of scientific research with translation medical benefits regarding the LT. The literature has a great tendency, improvements and investments in the study of translational medicine in LT. Innovative studies and technologies from basic science help to clarify clinical doubts. Moreover, evidence increases the importance of scientific research in quality of clinical practice care.
\end{abstract}

Keywords: Liver transplantation (LT); transplantation; systematic review; translational medical research

Received: 27 August 2018; Accepted: 28 October 2018; Published: 12 November 2018.

doi: $10.21037 / \operatorname{tgh} .2018 .10 .14$

View this article at: http://dx.doi.org/10.21037/tgh.2018.10.14

\section{Introduction}

Translational medicine aims to introduce innovations from basic research to clinical development and has become a priority. Nevertheless, there is still a vast challenge to the arrival of new treatments and their real benefits for practical medicine (1). Indeed, advances are not sustained by the absence of basic research, and therefore strategies and a methodology have been shaped in order to develop new treatment, mainly for complex diseases that demand better resolutions (1).

Liver transplantation (LT) is an efficacy approach and complex therapeutic technique in medicine. Despite of all basic research accomplished for this therapeutic method, this procedure still has many complications that require scientific models in order to improve the results (2). Additionally, promoting the validation of studies in precision medicine, immunological and surgical fields (including genome and epigenome studies), nanotechnology, signaling 
pathways, and biobanking could improve the advances of translational research and personalized medicine toward LT, offering potential solutions for further advancement through better integration between health care, academia, and industry (3).

The purpose of this literature systematic review was to analyze the translational process in the specific setting of LT, including liver ischemia-reperfusion injury (IRI), immunosuppression, clinical and surgical complications, small-for-size syndrome (SFSS), rejection, and ongoing innovations (liver machine, liver preservation, artificial livers, and regenerative medicine).

\section{Methods}

\section{Identification and selection of the studies}

This literature systematic review was performed to up to date the translational medical research in LT. The MedlinePubMed, Embase, Cochrane Databases (Controlled Trials and systematic review) and LILACS databases were electronically searched for articles published from January 2000 to October 2016, and updated in 19 October 2016.

The Mesh-terms utilized in Medline-PubMed database for literature search were developed using the PICO structure: patient, intervention, comparison or control, outcome. The Mesh-terms were used in combination with "OR". The results for the search Mesh-terms used "P" (Patients) were associated with the result that formed with the "I" (Intervention), using the "AND" and "NOT" operators.

The Medline-PubMed search was conducted in PubMed (www.ncbi.nlm.nih.gov/pubmed) and used the Mesh-terms: ((((“"Liver Transplantation”[Mesh]) AND “Translational Medical Research”[Mesh]) and ((((("Liver Transplantation”[Mesh]) AND “Translational Medical Research"[Mesh]) OR "Genomics”[Mesh]) OR "Epigenomics"[Mesh]) OR "Molecular Targeted Therapy"[Mesh]) OR "Bioethics"[Mesh])))). The equal strategy was used the others databases in the Embase (www.embase.com) and LILACS (http://lilacs.bvsalud.org) with the terms: ((((“"Liver Transplantation”[Mesh]) AND “Translational Medical Research”[Mesh]). The Cochrane Library Database (http://www.cochrane.org) was searched for registered and published systematic reviews (CDSR) and clinical trials (CCTR) on the management of LT and Translational Medical Research.

\section{Inclusion and exclusion criteria}

Selection criteria were performed within the research question with the PICO structure; therefore, randomized controlled trials, non-randomized controlled trials, or comparative clinical studies and others were included. Specific analysis and article selection in the LT surgical approach include the following topics: liver IRI; immunosuppression; complications: clinical and surgical; SFSS; rejection; and miscellaneous (liver machine and liver preservation; artificial liver and regenerative medicine; and experimental LT model).

\section{Data collection, analysis, and critical evaluation}

Independently the reviewers were assessed the studies quality and extracted data. The quality and selection of the studies data was evaluated by 2 researchers (LS Nacif and $\mathrm{V}$ Kim). In case of discordance, the researchers promoted a consensus to select the final verdict. The study design and quality of the studies, level of evidence, and article choice were based on the article's close relation to the topic of this review.

\section{Results}

\section{Study selection and study quality}

Initially the search found 773 articles. The entire study selection and description are detailed in Figure 1.

The characteristics of all search and databases were demonstrated on Table 1. Cochrane Library Database (http://www.cochrane.org) literature was searched for registered and published systematic reviews (CDSR) and clinical trials (CCTR) on the management of LT and Translational Medical Research (Table 1).

Articles selection with PICO structure were summarized in Supplementary files.

In the qualitative analysis of the present study we selected 44 studies for further analysis (4-23), the specific analysis was demonstrated on Figure 1 and Table 2 (24-47).

Qualitative analysis evaluation of the selected articles was follow below as liver IRI ( $n=9)$; immunosuppression $(n=16)$; SFSS $(n=3)$; acute cellular rejection (ACR) $(n=11)$; liver machine and preservation; artificial livers and regenerative medicine $(n=5)(4-23)$. The sensitive analysis shows us the vast presence of prospective original studies in these 


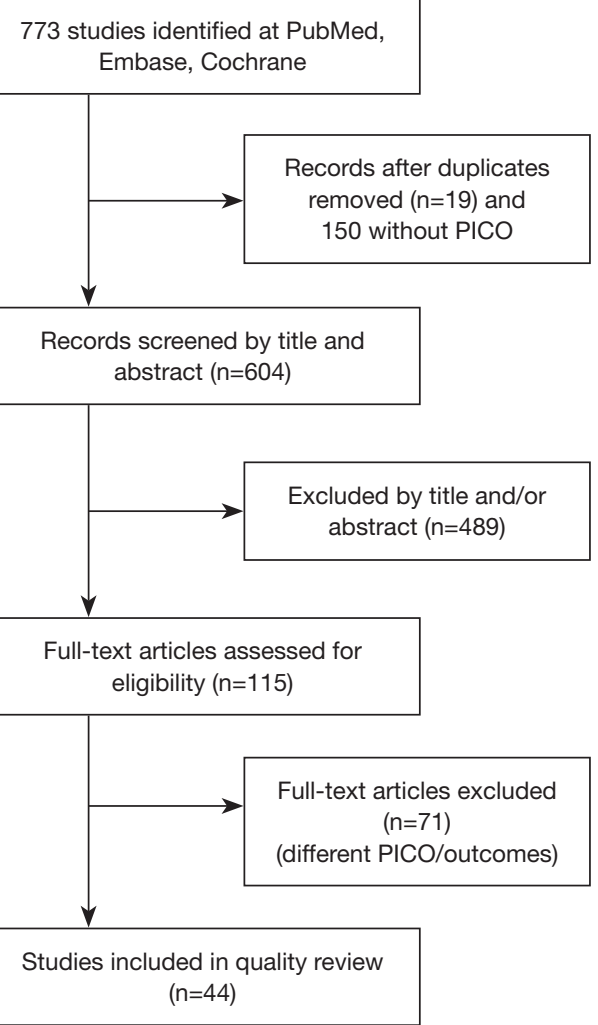

Figure 1 Flowchart of the study selection.

Table 1 Characteristics of all search and databases

\begin{tabular}{lcccc}
\hline Search terms & PubMed & Embase & Cochrane & Total \\
\hline 1 & 6 & 222 & 11 & 239 \\
2 & 53 & 330 & 1 & 384 \\
Total & 68 & 693 & 12 & 773 \\
\hline
\end{tabular}

Search 1: 'Liver Transplantation' AND 'translational research'; search 2: (Epigenomics OR Genomics OR Molecular Targeted Therapy) AND Liver Transplantation).

fields with more than 33 articles selected, the others was retrospective and reviews. The articles selected in the search were detailed and demonstrated in Table 2 (24-47). The selected articles were initially tabulated and characterized according to study type and PICO structures (Table 2).

\section{Discussion}

The present subject of this article shows us the important topic from "bench to bedside" is being re-thought around the world in the scientific and health-care communities.
An integrated institutional, multidisciplinary medical and research approach for the application of translational medicine promotes the validation of studies to translate to the clinical and surgical fields regarding LT. Indeed, diverse advances on translational research have been made over the past decades in the field of LT in an attempt to increase organ utilization and improve the health care for these patients.

Liver IRI is an important complication from hemorrhagic shock, large resection, and transplant. IRI in general is a dynamical manner with two stages: the local insult on ischemia phase and reperfusion phase with inflammation mediators (12). Regarding the LT process, these injuries occur at three distinct steps: firstly, the liver is stored at $0{ }^{\circ} \mathrm{C}$ to $4{ }^{\circ} \mathrm{C}$ after explanted from the donor (cold ischemia); then followed by the vascular anastomosis (warm ischemia). The ischemia period increases the liver temperature $0.5^{\circ} \mathrm{C} /$ minute. Liver reperfusion configures the third step $(8,10,11)$. Over the last decade, the prevention of early graft failure was performed using some therapeutic approach and donorrecipient well match strategies to prevent and decrease the IRI effects.

Immunosuppressive therapy has been optimized and evolving over the last years following LT (2). The therapeutic options vary from diverse types of agents and depend on the specific patient whether one should use the immunosuppression agent alone or in association. The types of LT immunosuppression drugs include: calcineurin inhibitors (CNIs), cyclosporine (CsA) or TAC; mycophenolate mofetil (MMF), azathioprine (AZA), mTOR inhibitors (rapamycin), and steroids (methylprednisolone or prednisone) (2). Post-transplant acute or chronic rejection and fibrosis are even difficulties to obtaining longterm survival in LT. Some translational studies show us interesting advances in this field, the mostly studies found in this review was regarding the acute cellular rejection $(n=11)$ and immunosuppression $(\mathrm{n}=16)$.

Chronic kidney disease (CKD) after liver transplant is one of the biggest clinical problems that arise to be related with genetic and non-genetic determinants. CNI is considered the main guilty in the development of CKD after LT (15). Kidney injury is usual in recipients with cirrhosis and related with decrease of survival rate after LT. This dysfunction perhaps associated to damage or functional alterations and can be better with following the LT.

Another poorly understood complication in LT is the concept of early allograft dysfunction (EAD), which demonstrates post-transplantation with increase serum 
Table 2 Characteristic of studies with liver transplantation and translational medical research

\begin{tabular}{|c|c|c|c|c|c|}
\hline Reference year & $\begin{array}{l}\text { Type of } \\
\text { article }\end{array}$ & Sample & $\mathrm{N}$ & Intervention & Outcomes \\
\hline \multicolumn{6}{|c|}{ Ischemia-reperfusion (IRI) } \\
\hline Zhuang 2016 (5) & Original & Animal & - & $\begin{array}{l}\text { Dichloroacetate } \\
\text { diisopropylamine }\end{array}$ & $\begin{array}{l}\text { Recovery of donor liver function after } \\
\text { transplantation }\end{array}$ \\
\hline Jassem 2009 (7) & Original & Human & $19 / 16$ & $\mathrm{IPC}(\times \mathrm{IRI})$ & $\begin{array}{l}\text { Reduction in the expression of immune response } \\
\text { genes and promotion of those involved in } \\
\text { protection and repair }\end{array}$ \\
\hline Cursio 2010 (10) & Leading & - & - & Caspase inhibitors & Cold ischaemia/normothermic reperfusion injury \\
\hline Selzner $2012(11)$ & Review & - & - & - & $\begin{array}{l}\text { Mechanisms of pre-, post-, and remote } \\
\text { conditioning of solid organs }\end{array}$ \\
\hline Zhai 2013 (12) & Review & - & - & - & $\begin{array}{l}\text { Innate-adaptive immune crosstalk and cell } \\
\text { activation cascades }\end{array}$ \\
\hline Immunosuppression & & - & - & - & \\
\hline Goto 2014 (13) & Abstract & - & - & $\begin{array}{l}\text { Anti-nuclear histone } \\
\text { H1antibody }\end{array}$ & Histone $\mathrm{H} 1$ was upregulated during liver fibrosis \\
\hline Nakano 2010 (14) & $\begin{array}{l}\text { Abstract } \\
(p-194)\end{array}$ & Animal (rat) & - & Hepatic mast cells, OLT & $\begin{array}{l}\text { Stem cell factor is an important factor for } \\
\text { proliferation and maturation of mast cells }\end{array}$ \\
\hline Fukudo 2008 (18) & Original & Human & 60 & $\begin{array}{l}\text { TAC,living-donor liver } \\
\text { transplantation (LDLT) }\end{array}$ & $\begin{array}{l}\text { CYP3A5*1 genotype as well as the MDR1 mRNA } \\
\text { level in enterocytes contributes to interindividual } \\
\text { variation in the CL/F of TAC in adult recipients early } \\
\text { after living-donor liver transplantation }\end{array}$ \\
\hline Crettol 2008 (19) & Original & Human & 64 & $\begin{array}{l}\text { Cyclosporine, renal, liver or } \\
\text { lung transplant }\end{array}$ & $\begin{array}{l}\text { ABCB1 polymorphisms ( } 1199 \mathrm{~A} \text { and } 3435 \mathrm{~T} \text { carriers) } \\
\text { influence cyclosporine intracellular concentration }\end{array}$ \\
\hline Smith $2008(20)$ & Original & Human & 163 & $\begin{array}{l}\text { Calcineurin inhibitors (CNIs), } \\
\text { LT patients receiving CNIs } \\
\text { for at least } 3 \text { years }\end{array}$ & $\begin{array}{l}\text { CYP2C8*3 is associated with a higher risk of } \\
\text { developing renal toxicity in patients treated } \\
\text { chronically with CNIs }\end{array}$ \\
\hline Chen 2013 (21) & Original & Human & 96 & TAC, LT & $\begin{array}{l}\text { Combined SNPs of donor CYPA5 rs } 776746 \text {, IL6 } \\
\text { rs } 1800796 \text {, and recipient CYP3A5 rs } 776746 \text { have } \\
\text { a greater effect on TAC metabolism than CYP3A5 } \\
\text { rs } 776746\end{array}$ \\
\hline Levitsky 2013 (22) & Original & Human & 20 & TAC to Sirolimus, LT & $\begin{array}{l}\mathrm{CNI} \text { to } \mathrm{SRL} \text { conversion after } \mathrm{LT} \text { could take } \\
\text { advantage of the regulatory properties of } S R L\end{array}$ \\
\hline
\end{tabular}

Table 2 (continued) 
Table 2 (continued)

\begin{tabular}{|c|c|c|c|c|c|}
\hline Reference year & $\begin{array}{l}\text { Type of } \\
\text { article }\end{array}$ & Sample & $\mathrm{N}$ & Intervention & Outcomes \\
\hline Chen 2014 (23) & Original & Human & 96 & TAC, LT & $\begin{array}{l}\mathrm{Hb} \text {, donor CYP3A5, NR113 gene polymorphisms, } \\
\text { and recipient CYP3A5 gene SNPs were associated } \\
\text { with TAC pharmacokinetics. }\end{array}$ \\
\hline Kurian 2015 (24) & Original & Human & $40 / 36$ & EAD/non-EAD & $\begin{array}{l}\text { Relevant pathways (PPARa and NF-kB) and targets } \\
\text { (CXCL1, IL1, TRAF6, TIPARP, and TNFRSF1B) are } \\
\text { associated with the phenotype of EAD }\end{array}$ \\
\hline Elens 2007 (26) & $\begin{array}{l}\text { Original, } \\
\text { prospective }\end{array}$ & Human & 150 & TAC, Liver donors & $\begin{array}{l}\text { CYP3A5 SNPs in liver tissue is significantly } \\
\text { associated with TAC dose requirement; } \\
\text { SLCO1B1 seem to influence early trough blood } \\
\text { concentrations, SNPs in ABCB1 seem to influence } \\
\text { the TAC hepatic levels and the graft outcome }\end{array}$ \\
\hline Li 2015 (28) & Review & - & - & - & $\begin{array}{l}\text { Roles of CXCL4 and CXCL4L1 in the pathogenesis } \\
\text { of chronic liver allograft dysfunction }\end{array}$ \\
\hline \multicolumn{6}{|c|}{ Small-for-size syndrome } \\
\hline Hsu 2015 (29) & Original & Animal (rat) & - & $\begin{array}{l}\text { Granulocyte colony- } \\
\text { stimulating factor (G-CSF), } \\
\text { dipeptidyl peptidase IV } \\
\text { (DPP-IV) inhibitor }\end{array}$ & $\begin{array}{l}\text { Combined treatment may synergistically induce } \\
\text { migration and differentiation of recipient-derived } \\
\text { stem cells into the hepatic progenitor cells }\end{array}$ \\
\hline Chen 2011 (30) & Original & Animal (rat) & - & $\begin{array}{l}\text { miRNA expression profile, } \\
\text { partial hepatectomy }(\mathrm{PH}) \mathrm{LT}\end{array}$ & $\begin{array}{l}\text { Down-regulated miRNAs play a pivotal role in } \\
\text { promoting the growth of small size grafts and the } \\
\text { remaining liver after } \mathrm{PH}\end{array}$ \\
\hline Wei 2015 (33) & Original & Animal (rat) & - & $\begin{array}{l}\text { Biomarkers of the chronic } \\
\text { rejection, OLT }\end{array}$ & $\begin{array}{l}\text { CLU, Lcn2 and Krt19 were identified and quantified } \\
\text { as early and reliable biomarkers }\end{array}$ \\
\hline Xu 2014 (34) & Original & Animal (rat) & - & $\begin{array}{l}\text { Biomarkers of immune } \\
\text { response, OLT }\end{array}$ & $\begin{array}{l}\text { HPX serves as a negative predictor for AR of liver } \\
\text { allograft }\end{array}$ \\
\hline Cheng 2010 (35) & Original & Animal (rat) & - & $\begin{array}{l}\text { Global protein expression } \\
\text { changes in liver allograft } \\
\text { during AR }\end{array}$ & $\begin{array}{l}\text { Altered protein expressions act coordinately in } \\
\text { hepatocyte dysfunction by depressed energy, } \\
\text { enhanced oxidative stress-induced molecular } \\
\text { damage and restrained biotransformation }\end{array}$ \\
\hline Wu 2009 (36) & Original & Animal (rat) & - & $\begin{array}{l}\text { Variation of serum } \\
\text { metabolites, OLT }\end{array}$ & $\begin{array}{l}\text { Changes in metabonomic profiles reflected in the } \\
\text { graft injury are correlated with histological changes } \\
\text { instead of classical liver function }\end{array}$ \\
\hline
\end{tabular}

Table 2 (continued) 
Table 2 (continued)

\begin{tabular}{|c|c|c|c|c|c|}
\hline Reference year & $\begin{array}{l}\text { Type of } \\
\text { article }\end{array}$ & Sample & $\mathrm{N}$ & Intervention & Outcomes \\
\hline Gehrau 2016 (37) & Abstract & Human & 22 & $\begin{array}{l}\text { DNA methylation patterns, } \\
\text { post-LT }\end{array}$ & $\begin{array}{l}\text { CpGs methylation identified apoptosis activation } \\
\text { signaling, ubiquitin protein degradation, and cell } \\
\text { cycle regulation. CpGs hypomethylation increases } \\
\text { in liver cell death and G1/S cell cycle check-point }\end{array}$ \\
\hline Taubert 2012 (38) & $\begin{array}{l}\text { Original, } \\
\text { prospective }\end{array}$ & Human & 151 & $\begin{array}{l}\text { Intrahepatic T cell infiltration } \\
\text { pattern in correlation to the } \\
\text { severity of ACR }\end{array}$ & $\begin{array}{l}\text { Active role of regulatory T cells (Tregs) in controlling } \\
\text { rejection }\end{array}$ \\
\hline Joshi 2013 (39) & Original & Human & 29 & $\begin{array}{l}\text { Intragraft miRNA expression } \\
\text { profiles, recurrent HCV from } \\
\text { ACR post-LT }\end{array}$ & $\begin{array}{l}\text { miRNA-19a and miRNA-20a could represent } \\
\text { potential serum biomarkers for fibrosis progression }\end{array}$ \\
\hline Uesugi 2014 (40) & Original & Human & 412 & TAC, ACR post-LT & $\begin{array}{l}\text { Graft liver CYP3A5*1 genotype might increase the } \\
\text { risk for ACR after living-donor LT }\end{array}$ \\
\hline \multicolumn{6}{|l|}{ Miscellaneous } \\
\hline Yagi 2013 (43) & Original & Animal (rat) & - & $\begin{array}{l}\text { Venous systemic oxygen } \\
\text { persufflation (VSOP) with } \\
\text { nitric oxide (NO) gas, partial } \\
\text { liver preservation and LT }\end{array}$ & $\begin{array}{l}\text { Novel and safe preservation method that improve } \\
\text { liver regeneration after transplantation }\end{array}$ \\
\hline Zhou 2014 (44) & Original & Animal (rat) & - & Arterialized OLT & Done quickly with a high patency rate \\
\hline Dong 2016 (45) & Original & Animal (pig) & - & $\begin{array}{l}\text { Development of an organ } \\
\text { culture system }\end{array}$ & $\begin{array}{l}\text { Liver function can be maintained in ex situ organ } \\
\text { culture without the use of erythrocytes }\end{array}$ \\
\hline
\end{tabular}

Number and percentages. EAD, Early allograft dysfunction; IPC, Ischemic preconditioning; IRI, ischemia/reperfusion injury; LT, Liver Transplantation; TAC, Tacrolimus; TMR, Translational Medical Research.

transaminases, cholestasis and coagulopathy (28). Chronic liver graft dysfunction is the main morbidity and late graft waste cause after LT.

Small remnant of the liver or a small-for-size liver commonly induces SFSS or post-hepatectomy liver failure (PHLF). An inordinate portal flow for these small livers is primordial factor for SFSS (45). Some of these modalities, as living donor LT or split livers, were solutions to the liver donor shortages and decrease the waiting-list time for the patients to the LT procedure (45). This study shows us some specific papers on raising the mortality rate and require the progress of organ culture system that livers can be cultured and hold ex situ for a long time.

Regenerative medicine has demonstrated feasible for "bench-to-bedside" translational research in cell progress, stem cell biology and tissue engineering (46). We found some papers regarding models of functioning livers that have been engineered application "natural tissue" scaffolds and are in evolution to produce kidneys, pancreas, and small intestines.

The regenerative potential of the liver is unparalleled with its regeneration recover after damage from ischemia, resection, and acute or chronic rejection (47). The signatures of gene expression were characterized for these events and may be possible to precise therapies to decrease damage, improve regeneration and survival rates.

The limitations of this study were that we were unable to perform a meta-analysis due to the diversity and heterogeneity of the papers studied. This study has others limitations; the specific outcomes of interest have been 
evaluated separated. In this subject, more randomized clinical trials are needed to focus on translational medicine and LT. The benefit of this systematic review was to evaluate more patients with important positive factors in the liver transplant field. This is an original research that we described a systematic review of articles that shows us an important topic from "bench to bedside" is being rethought around the world in the scientific and health-care communities. Indeed, diverse advances on translational research have been made over the past decades in the field of LT in an attempt to increase organ utilization and improve the health care for these patients.

\section{Conclusions}

Translational medicine was initially conceived as an integrated institutional, multidisciplinary, medical research approach toward the application of "bench-to-bedside" rather than promoting advancement and technologies in LT around the world in the scientific and health-care communities

This systematic review demonstrated due to the increasing number of publications that have been improvements regarding the study of translational medicine in LT. Innovative studies and technologies from basic science help to clarify clinical doubts and basic scientific research has increasingly contributed to the quality of care in clinical practice.

\section{Acknowledgements}

None.

\section{Footnote}

Conflicts of Interest: The authors have no conflicts of interest to declare.

\section{References}

1. Mankoff SP, Brander C, Ferrone S, et al. Lost in Translation: Obstacles to Translational Medicine. J Transl Med 2004;2:14.

2. Nacif LS, Pinheiro RS, de Arruda Pécora RA, et al. ReTransplantation, Higher Creatinine Levels in Hepatitis C Virus Patients, and Donor Age Are Predictors of Mortality in Long-Term Analysis of Late Acute Rejection in Liver Transplantation. Ann Transplant 2017;22:9-16.
3. Collins FS, Varmus H. A new initiative on precision medicine. N Engl J Med 2015;372:793-5.

4. Qin J, Zhou J, Dai X, et al. Short-term starvation attenuates liver ischemia-reperfusion injury (IRI) by Sirt1-autophagy signaling in mice. Am J Transl Res 2016;8:3364-75.

5. Zhuang Z, Lian P, Wu X, et al. Abate Cytochrome $\mathrm{C}$ induced apoptosome to protect donor liver against ischemia reperfusion injury on rat liver transplantation model. Am J Transl Res 2016;8:1738-47.

6. Emadali A, Muscatelli-Groux B, Delom F, et al. Proteomic analysis of ischemia-reperfusion injury upon human liver transplantation reveals the protective role of IQGAP1. Mol Cell Proteomics 2006;5:1300-13.

7. Jassem W, Fuggle S, Thompson R, et al. Effect of ischemic preconditioning on the genomic response to reperfusion injury in deceased donor liver transplantation. Liver Transpl 2009;15:1750-65.

8. Kristo I, Wilflingseder J, Kainz A, et al. Effect of intraportal infusion of tacrolimus on ischaemic reperfusion injury in orthotopic liver transplantation: a randomized controlled trial. Transpl Int 2011;24:912-9.

9. Raza A, Dikdan G, Desai KK, et al. Global gene expression profiles of ischemic preconditioning in deceased donor liver transplantation. Liver Transpl 2010;16:588-99.

10. Cursio R. Caspase inhibition in liver transplantation: from basic research to clinical studies. HPB (Oxford) 2010;12:1-3.

11. Selzner N, Boehnert M, Selzner M. Preconditioning, postconditioning, and remote conditioning in solid organ transplantation: basic mechanisms and translational applications. Transplant Rev (Orlando) 2012;26:115-24.

12. Zhai Y, Petrowsky H, Hong JC, et al. Ischaemiareperfusion injury in liver transplantation--from bench to bedside. Nat Rev Gastroenterol Hepatol 2013;10:79-89.

13. Goto S, Hsu L, Nakano T, et al. Significance of postliver transplantation induced anti-histone $\mathrm{H} 1$ antibody for prevention of chronic rejection and liver fibrosis. Transplantation 2014;98:309.

14. Nakano T, Goto S, Lai CY, et al. Immunological aspects and therapeutic significance of an autoantibody against histone $\mathrm{H} 1$ in a rat model of concanavalin A-induced hepatitis. Immunology 2010;129:547-55.

15. Parikh CR, Belcher JM. Reconsidering a "chopped liver": the need for improving glomular filtration rate estimation for hepatic transplantation. Hepatology 2014;59:1242-5.

16. Egawa H, Miyagawa-Hayashino A, Haga H, et al. Noninflammatory centrilobular sinusoidal fibrosis in pediatric 
liver transplant recipients under tacrolimus withdrawal. Hepatol Res 2012;42:895-903.

17. Hsu LW, Goto S, Nakano T, et al. Immunosuppressive activity of serum taken from a liver transplant recipient after withdrawal of immunosuppressants. Transpl Immunol 2007;17:137-46.

18. Fukudo M, Yano I, Yoshimura A, et al. Impact of MDR1 and CYP3A5 on the oral clearance of tacrolimus and tacrolimus-related renal dysfunction in adult livingdonor liver transplant patients. Pharmacogenet Genomics 2008;18:413-23.

19. Crettol S, Venetz JP, Fontana $M$, et al. Influence of ABCB1 genetic polymorphisms on cyclosporine intracellular concentration in transplant recipients. Pharmacogenet Genomics 2008;18:307-15.

20. Smith HE, Jones JP 3rd, Kalhorn TF, et al. Role of cytochrome $\mathrm{P} 4502 \mathrm{C} 8$ and 2J2 genotypes in calcineurin inhibitor-induced chronic kidney disease. Pharmacogenet Genomics 2008;18:943-53.

21. Chen D, Fan J, Guo F, et al. Novel single nucleotide polymorphisms in interleukin 6 affect tacrolimus metabolism in liver transplant patients. PLoS One 2013;8:e73405.

22. Levitsky J, Mathew JM, Abecassis M, et al. Systemic immunoregulatory and proteogenomic effects of tacrolimus to sirolimus conversion in liver transplant recipients. Hepatology 2013;57:239-48.

23. Chen D, Guo F, Shi J, et al. Association of hemoglobin levels, CYP3A5, and NR1I3 gene polymorphisms with tacrolimus pharmacokinetics in liver transplant patients. Drug Metab Pharmacokinet 2014;29:249-53.

24. Kurian SM, Fouraschen SM, Langfelder P, et al. Genomic profiles and predictors of early allograft dysfunction after human liver transplantation. Am J Transplant 2015;15:1605-14.

25. Béland K, Dore-Nguyen M, Gagné MJ, et al. Torque Teno virus in children who underwent orthotopic liver transplantation: new insights about a common pathogen. J Infect Dis 2014;209:247-54.

26. Elens L, Capron A, Kerckhove VV, et al 1199G>A and $2677 \mathrm{G}>\mathrm{T} / \mathrm{A}$ polymorphisms of ABCB1 independently affect tacrolimus concentration in hepatic tissue after liver transplantation. Pharmacogenet Genomics 2007; 17:873-83.

27. Tapirdamaz Ö, Hesselink DA, el Bouazzaoui S, et al. Genetic variance in ABCB1 and CYP3A5 does not contribute toward the development of chronic kidney disease after liver transplantation. Pharmacogenet
Genomics 2014;24:427-35.

28. Li J, Liu B, Yan LN, et al. The roles and potential therapeutic implications of CXCL4 and its variant CXCL4L1 in the pathogenesis of chronic liver allograft dysfunction. Cytokine Growth Factor Rev 2015;26:67-74.

29. Hsu LW, Goto S, Nakano T, et al. Prolonged survival by combined treatment with granulocyte colony-stimulating factor and dipeptidyl peptidase IV inhibitor in a rat small-for-size liver transplantation model. Hepatol Res 2015;45:804-13.

30. Chen X, Murad M, Cui YY, et al. miRNA regulation of liver growth after $50 \%$ partial hepatectomy and small size grafts in rats. Transplantation 2011;91:293-9.

31. Iguchi K, Hatano E, Yamanaka K, et al. Hepatoprotective effect by pretreatment with olprinone in a swine partial hepatectomy model. Liver Transpl 2014;20:838-49.

32. Nakano T, Lai CY, Goto S, et al. Immunological and regenerative aspects of hepatic mast cells in liver allograft rejection and tolerance. PLoS One 2012;7:e37202.

33. Wei W, Huang XH, Liang D, et al. A proteomic analysis of transplanted liver in a rat model of chronic rejection. Clin Res Hepatol Gastroenterol 2015;39:340-50.

34. Xu M, Tan C, Hu J, et al. Expression of hemopexin in acute rejection of rat liver allograft identified by serum proteomic analysis. Shock 2014;42:65-74.

35. Cheng J, Zhou L, Jiang JW, et al. Proteomic analysis of differentially expressed proteins in rat liver allografts developed acute rejection. Eur Surg Res 2010;44:43-51.

36. Wu Y, Tao Y, Liang L, et al. Metabonomic profile of rats with acute liver rejection. OMICS 2009;13:81-91.

37. Gehrau R, Bontha S, Mas V, et al. DNA methylation patterns and association with graft injury severity post liver transplantation. Am J Transplant 2016;16:378-9.

38. Taubert R, Pischke S, Schlue J, et al. Enrichment of regulatory $\mathrm{T}$ cells in acutely rejected human liver allografts. Am J Transplant 2012;12:3425-36.

39. Joshi D, Salehi S, Brereton H, et al. Distinct microRNA profiles are associated with the severity of hepatitis $\mathrm{C}$ virus recurrence and acute cellular rejection after liver transplantation. Liver Transpl 2013;19:383-94.

40. Uesugi M, Kikuchi M, Shinke H, et al. Impact of cytochrome $\mathrm{P} 4503 \mathrm{~A} 5$ polymorphism in graft livers on the frequency of acute cellular rejection in livingdonor liver transplantation. Pharmacogenet Genomics 2014;24:356-66.

41. Bonaccorsi-Riani E, Pennycuick A, Londoño MC, et al. Molecular Characterization of Acute Cellular Rejection Occurring During Intentional Immunosuppression 
Withdrawal in Liver Transplantation. Am J Transplant 2016;16:484-96.

42. Ningappa M, Ashokkumar C, Higgs BW, et al. Enhanced B Cell Alloantigen Presentation and Its Epigenetic Dysregulation in Liver Transplant Rejection. Am J Transplant 2016;16:497-508.

43. Yagi S, Nagai K, Kadaba P, et al. A novel organ preservation for small partial liver transplantations in rats: venous systemic oxygen persufflation with nitric oxide gas. Am J Transplant 2013;13:222-8.

44. Zhou S, Palanisamy AP, McGillicuddy JW, et al. New method of stent-facilitated arterial reconstruction for

doi: $10.21037 / \operatorname{tgh} .2018 .10 .14$

Cite this article as: Nacif LS, Kim V, Galvão F, Ono SK, Pinheiro RS, Carrilho FJ, D'Albuquerque LC. Translational medical research and liver transplantation: systematic review. Transl Gastroenterol Hepatol 2018;3:91. orthotopic mouse liver transplantation. J Surg Res 2014;187:297-301.

45. Dong J, Xia L, Shen H, et al. Growing a whole porcine liver organ ex situ for six hours without red blood cells or hemoglobin. Am J Transl Res 2016;8:2562-74.

46. Orlando G, Baptista P, Birchall M, et al. Regenerative medicine as applied to solid organ transplantation: current status and future challenges. Transpl Int 2011;24:223-32.

47. Hashmi SK, Baranov E, Gonzalez A, et al. Genomics of liver transplant injury and regeneration. Transplant Rev (Orlando) 2015;29:23-32. 


\section{Articles selection with PICO structure}

(I) Liver transplantation AND Translational Medical Research

Duplicates: 5

("Liver Transplantation”[Mesh]) AND “Translational Medical Research"[Mesh]

Cochrane: 11

("Liver Transplantation”[Mesh]) AND “Translational Medical Research"[Mesh]

PubMed: 6

'Liver Transplantation' AND ‘translational research'

Embase: 222
(II) (Epigenomics OR Genomics OR Molecular Targeted Therapy) AND Liver Transplantation Duplicates: 14 (((“Epigenomics”[Mesh]) OR “Genomics”[Mesh]) OR "Molecular Targeted Therapy”[Mesh]) AND "Liver Transplantation"[Mesh]

PubMed: 53

(Genomics OR Epigenetics OR molecularly targeted therapy) AND Liver Transplantation

Embase: 330

(Genomics OR Epigenomics OR molecularly targeted therapy) AND Liver Transplantation

Cochrane: 1 